\title{
A Model To Detect Forest Change Relating To Mining Using Google Earth Engine Application In Belitung Island, Indonesia
}

\author{
Ratiranjan Jena, Centre for Advanced Modelling and Geospatial \\ Information Systems (CAMGIS), Faculty of Engineering and IT, \\ University of Technology Sydney, NSW 2007, Australia
}

Biswajeet Pradhan, Centre for Advanced Modelling and Geospatial Information Systems (CAMGIS), Faculty of Engineering and IT, University of Technology Sydney, NSW 2007, Australia

* Correspondence: Biswajeet Pradhan*, Biswajeet.Pradhan@uts.edu.au

\begin{abstract}
:
Belitung Island is one of the biodiversity hotspots in Indonesia that is best known for its multi-use landscape, tourism, large agricultural land, tin mining and all other activities. The main earning possibility of local people of the island is most efficiently lies in coastal activities and tin mining. Main challenges are persistent cloud cover over the steep and vegetated terrain that creates a problem in forest change mapping. This research was conducted to identify and visually analyse the forest loss or gain due to tin mining activity and settlement along with the consequences of illegal logging using the Google earth engine application. Furthermore, this study will also help to understand the areas of water bodies filled after mining making it inactive. Therefore, NDVI and MNDWI analysis have been conducted to calculate the index values using the (GEE) Google earth engine and graphically presented. Landsat +ETM, MODIS global land cover, Hansen global forest change and other remote sensing data applied to conduct this research. The results obtained from this study shows that the width of forestry land cover is decreased gradually from 2012 to 2017 and the active tin mining, agricultural land, and settlement are widely increased. The inactive tin-mined areas are filled with water that can be well understood from the elevation modelling. Furthermore, the forest gain is also increasing mildly as per the results of change detection in forest gain analysis from 2012 to 2017 . This clearly indicates the change of forest resulting due to the active tin mining and inactive tin-mined water filled land as well as the human settlement. Keywords: Forest change; Mining activity; Google earth engine; GIS; Remote sensing
\end{abstract}

\section{INTRODUCTION}

Belitung, an island of Indonesia is situated within the BangkaBelitung province. The island is divided into two main parts such as Belitung regency and East Belitung regency. It lies on a strategic location of trading and economic route of South-east Asia. Belitung people are mostly concentrated and settled near to the beaches because of tourism and coastal fishing. Some illegal mining activity is happening on the island while some tin mining is initiated by the Indonesian government located in central and eastern region of the island. The type of mining is generally opencast where; the forest growth cannot develop anymore. In general, the tin mining in Belitung Island can be found within the deep forest that is uncontrolled and the gain of forestland due to conversion is almost impossible [1,2].The condition of natural carbon stock has been damaged by the illegal activities and private mining activities. The famous biodiversity of the Island is affected by illegal deforestation activities that makes the extinction of trees and animal species because of the waste that released from the mining being mixed with sea and water bodies [1]. The tin mining and valuable activities in coastal regions influencing the growth of human settlement to be centred in the coastal areas. Ref. [6-14] described in their research that the settlement generally cause the change of the forestland cover dominantly. Therefore, it is responsible for the annual decrease 
of the forests as well as natural carbon stocks. Another main reason for the change of forest cover is the continuous occurrence of tin mining in Belitung Island. The functional change of the forest cover and coastal tourism areas into mining and human settlement increases up to $70 \%$ from 19952017(Central Bureau Statistics, Belitung District, 2016). As the land changes increase the $\mathrm{CO}_{2}$ excessively, deforestation due to human settlement and corrupted environment of vegetation raise concerning issues in every global debate [16]. Ref. [17] described that forests are not simply a bunch of woods that is a source of the economy not only temporarily helps in national income but also they have global commodity potentials for the environment. The uncontrolled forest loss due to any reason might create an unexplainable disaster. Therefore, a large forest has the capability of absorbing the $\mathrm{CO}_{2}$; forest gain should be the latest paradigm in the forestry sector, which will be a global opportunity for Indonesia. As it is a developing county, forest gain and increasing the national income through Clean Development Mechanism (CDM) [17] should be applied. Mineral exploration is the term of development at a specific location that confront variable challenges by making a misbalance in between the resources for prosperity, developmental strategy and the safety for the environment as well as social welfare [20]. Land and environmental degradation can be caused due to mining activities that can affect the livelihood health system of local people [15, 17]. However, opencast tin mining can acidify the environment, water bodies and the toxic chemical increment may create a big problem. Therefore, these are responsible for the decrease in the availability of good quality water that results in the issue of water pollution. Because of the mining activity, the environment will be risky and corrupted that can affect the diversity of wildlife abundance [17-21]. Various enabled image-processing techniques have been used for land cover change detection [22, 23]. An advanced machine learning algorithm is an efficient technique, which is used in every sector of computational tasks that is capable of handling large volumes of image data. Google Earth Engine (https://earthengine.google.com/) is an efficient platform for large geospatial analysis, which is open-access effective for research purposes [3-5]. The platform is very simple that requires an online application and a user account to get into it. With a JavaScript coding system, Earth Engine helps for data collection that can be applied directly through the workspace option. It allows the users to make coding and developing algorithms and projects the results in that can be visually analysed. Earth Engine also provides other options for mapping implementation. Other algorithms have demonstrated to incorporate a world of imagery data and applied for automatic image classification for mapping purposes using Earth Engine. The analysis was focused on the loss of forestland cover related to tin mining and human settlement area within the period of 2012-2017. The main objective of this study is to develop a novel methodology and modified Hansen algorithm in the Google Earth Engine platform for mapping forest gain and loss and to make a correlation with mining and settlement activity. A secondary objective is to determine if the mines are active or inactive by analysing the elevation modelling that enables more accurate results of inactive mined areas are filled with water while active mines are without water bodies. MODIS global land cover change data, google earth images and field images are assessed for accuracy measurement by making a comparison with resulted maps. The forest loss mapping methodological workflow is reliable for the environmental planning and research update. Carbon stock in Belitung was approximately 125.640.153, 0 ton in 2015. This amount of carbon stock is significantly decreased as compared to 1995 namely $321.725 .572,6$ ton, which is the main challenging issue in this island $[5,6,7]$. Therefore, monitoring of forest change along with the planning to make a reversible of losses need to be done. This study will provide the modified methodology to detect the loss or gain and will help to develop the growth of forest land cover.

\section{MATERIALS AND METHODS}

\section{A. Study area}

Belitung Island is located in South East Asia at lat. and long. of $2^{\circ} 50^{\prime} \mathrm{S}$ and $107^{\circ} 55^{\prime} \mathrm{E}$, respectively. The population density of the island is approximately $56.63 / \mathrm{km} 2$. .The highest elevation of the island is $500 \mathrm{~m}$ known to have occurred as mount Tajam. Belitung Island is widely popular for the granitic abstract boulders and opal sand as well as white beaches. Belitung is the main source of valuable economic minerals such as tin, iron ore and silica sands and varieties of clay minerals. The sandy beaches and many offshore small brilliant looking islands are main places to become a larger part of the country's economy. The main beaches are Tanjung Tinggi Beach and Tanjung Kelayang Beach, with clear blue water, opal rich sand, and rocky sea beaches. The total area of the Belitung island is 480.010.000 ha. In 1995, the width of forest cover is $236.114,21$ ha, agriculture land $110.090,02$ ha, human settlement 25.430, 11 ha, active tin mining is 5.111,24 ha, and lakes formed after tin mine is around 29.420,24 ha. 


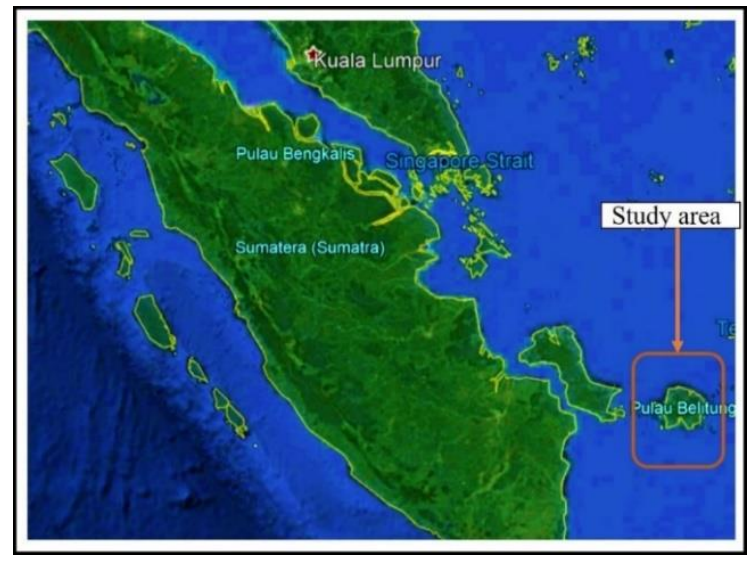

Figure 1. Study area.
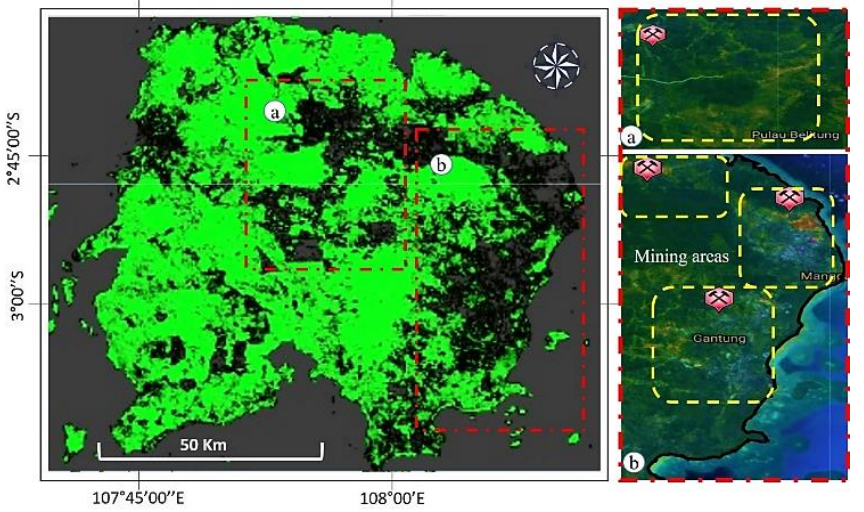

Figure 2. Represents the loaded Landsat 7 data in GEE (Google earth engine). Figure a) and b) are representing the mining areas of the Belitung Island.

\section{B. Materials}

In this research, various satellite images have been collected such as Landsat 7+ETM, MODIS for the visual analysis of change detection. Google earth images, Field images and various published research papers are used in this study to validate the obtained results. In addition, MODIS global land cover change images collected from the google earth engine workspace and used for the validation. We have used Hansen global forest change data from 2012 -2017 for the change detection, individually. The loss of forest generally represents the change of forest areas to non-forest areas that may be due to settlement or mining activity. Here, in this study, the values of 1 (loss) or 0 (no loss) are encoded for the forest changes. All the data have been collected from the USGS (LULC program) sources which are open access and freely available. Therefore, these data applied in the Google earth engine platform by using the JavaScript coding system to visually analyse and map the forest changes. The properties of data are well explained in the USGS official site as well as in Google earth engine workspace database. Total bands availability are 4 out of which, first and last bands are used as a reference for the multispectral imagery. The details description of the data applied in this research are presented in table 1 .

Table 1. Data used in this research.

$\begin{array}{llllll}\text { Data } & \text { Peri } & \text { Resolutio } & \text { Bands } & \text { Source } & \text { Purpose } \\ & \text { od } & n\end{array}$

\begin{tabular}{|c|c|c|c|c|c|}
\hline \multirow{2}{*}{$\begin{array}{l}\text { Landsat } \\
7+\text { ETM }\end{array}$} & & $30 \mathrm{~m}$ & & & NDVI \\
\hline & & & & & $\begin{array}{l}\text { MNDWI } \\
\text { calculatio } \\
\mathrm{n}\end{array}$ \\
\hline $\begin{array}{l}\text { Hansen } \\
\text { forest } \\
\text { change }\end{array}$ & $\begin{array}{l}201 \\
2- \\
201 \\
7\end{array}$ & $30 \mathrm{~m}$ & $\begin{array}{l}7 / 6 / 5 / 4 / \\
3\end{array}$ & USGS & $\begin{array}{l}\text { Change } \\
\text { detection } \\
\text { verificati } \\
\text { on }\end{array}$ \\
\hline MODIS & $\begin{array}{l}201 \\
7\end{array}$ & $30 \mathrm{~m}$ & & & $\begin{array}{l}\text { Change } \\
\text { detection } \\
\text { and } \\
\text { validation }\end{array}$ \\
\hline $\begin{array}{l}\text { Google } \\
\text { earth } \\
\text { images }\end{array}$ & $\begin{array}{l}201 \\
7\end{array}$ & $\begin{array}{l}\text { High } \\
\text { resolutio } \\
\text { n images }\end{array}$ & & $\begin{array}{l}\text { Google } \\
\text { earth Pro } \\
\text { applicatio } \\
\mathrm{n}\end{array}$ & $\begin{array}{l}\text { Validatio } \\
\mathrm{n}\end{array}$ \\
\hline
\end{tabular}

\section{Methodology}

The methodological flow chart is prepared for the clear presentation and analysis of the collected data. Satellite imagery, google earth imagery, field photos were also collected from various sources and used to find evidence of forest loss or gain that are mostly due to the tin mining and human settlement. However, this study also provides the evidence of the inactive tin mining are filled with water bodies. In the past, aerial photography, satellite imagery data applied by many 
researchers to make a correlation between mining activity, settlements with the forest loss or gain [24, 25, 26]. Later, researchers have applied various geophysical, geochemical and geotechnical studies to make the linkage between mining with forest loss or gain. However, satellite imageries have been applied as the base map in their research. The methodology involved google earth engine applications, image processing, band combination and satellite data acquisition. Normalised difference vegetation index (NDVI), Normalised difference water index (NDWI) and modified normalised difference water index (MNDWI), elevation modelling, identifying the water bodies as well as active mining areas also performed that developed acceptable logical results from this study. Firstly, landsat 7 data applied in google earth engine platform by making the project setting. In the second step, by applying the modified JavaScript code the forest loss and gain mapping performed individually for the whole period.

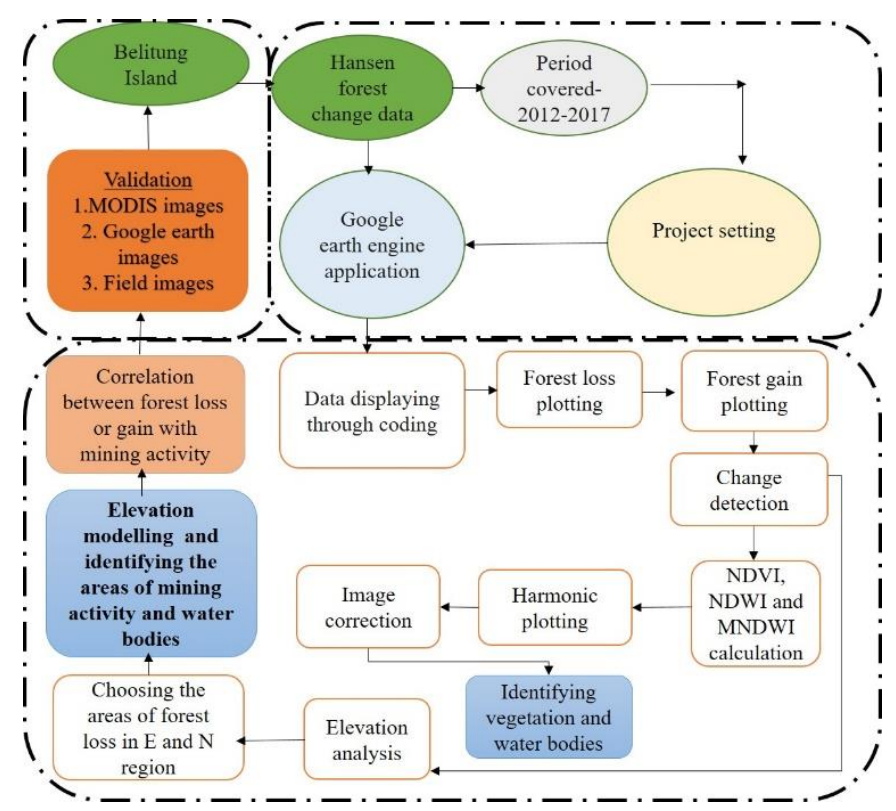

Figure 3. Overall methodological flowchart of the study.

Changes from 2012 to 2017 are visually analysed and identified the areas of forest loss or gain. NDVI, NDWI, MNDWI are calculated and plotted in a graph as well as by correcting the images with band combination water bodies and vegetation areas are identified. In the same stage, the newly projected elevation analysis applied to analyse the depth of various forest loss regions that helps to find out the mining activity along with water bodies. Therefore, Correlation between forest changes with mining activity applied after the analysis. In the third stage, validation of the results obtained from the study by using MODIS, Google earth images and field images have been performed. The methodological details are presented in figure 3.

\section{RESULTS AND DISCUSSION}

Using the current technological trends, this research has been conducted in association with a complete systematic calculation and mapping of forest changes using the google earth engine application. The study provides information about forest loss and gains with an individual coding approach. By analysing, the spatial data of land cover changes and various field images the mining activity and settlement areas can be easily interpreted. Therefore, empirically we made this study by using the Google earth engine workspace and identified the forest loss areas. In general, we analysed various data and conduct a correlative study with respect to mining activity, inactive mines and settlement in this region.

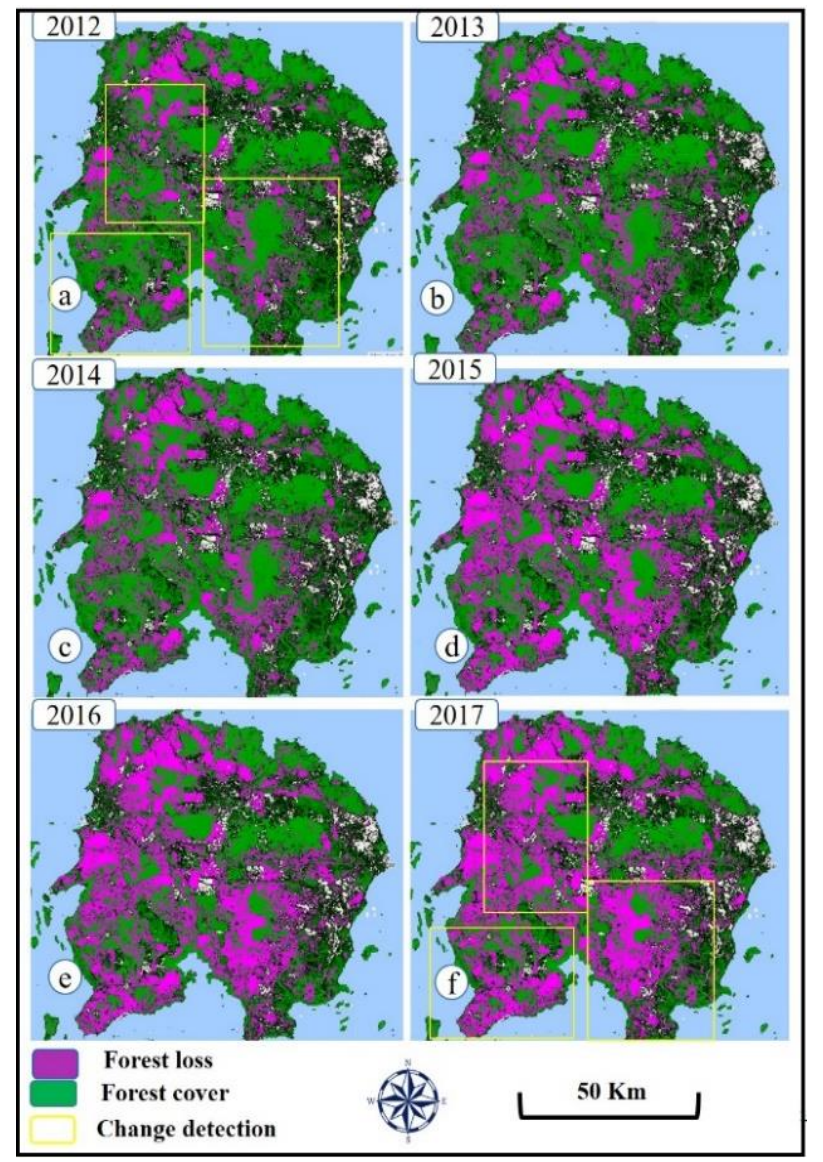

Figure 4. Visual change detection of forest loss in Belitung Island from 2012-2017. 
Spatial Model of forest change in Belitung Island in 20122017 was obtained from the analysis of satellite imagery. The land cover of the island can be classified as forest, agriculture land, active tin mine, inactive mine with water bodies and human settlement. Off course, there can be some changes every year in the forestry as well as other land covers. However, the changes need to be updated every year. The model obtained from the analysis of forest change shows the view of spatial change information that there have been changes of forest loss from the year 2012 up to 2017. The massive forest conversion in the island is generally due to tin mining, human settlement and palm oil trees, coconuts and other agricultural development conducted by their government and own community. The forest loss results shows that there is a huge change in forest loss between 2012 to 2017.

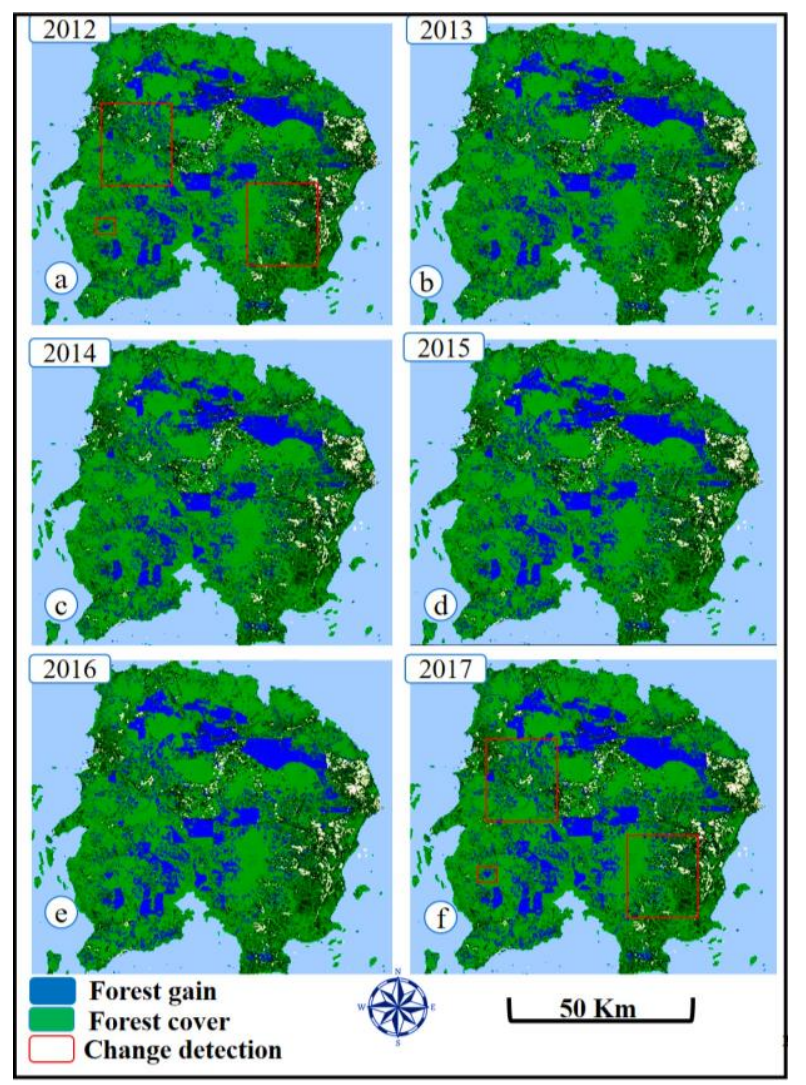

Figure 5. Visual change detection of forest gain in Belitung island from 2012-2017.

Mostly the changes can be found in the south and western region. The changes obtained from the results are marked through yellow boxes in the images. Accordingly, the forest gain analysis has been performed to find out the forest changes based on gaining without considering the modified land of agriculture. The analysis clearly provides excellent results of forest gain. Nevertheless, forest gain occurred at a very high amount. However, in between the year 2012-2017, there are not many changes can be found. The change detection analysis has been conducted by analysing the resulted images visually. Therefore, the changes in forset gain are very less and that was presented in figure 5 . The red color boxes plotted in the image represents the changes in forest gain. This analysis reveals that the largest area of forest cover was destroyed by illegal mining activity within the period of 2012 and 2017. The data resolution is low of 30-meter for which, the specific locations cannot be identified in this study. Therefore, there is a need of good quality data for better interpretation and mapping. Mining activity indirectly affects the forest land cover in quantity as well as in quality because of environmental pollution due to mining.

Table 2 Details of bands and palette types used for the analysis.

\begin{tabular}{|c|c|c|c|c|c|}
\hline Criteria & $\begin{array}{l}\text { Palette } \\
\text { types }\end{array}$ & $\begin{array}{l}\text { Tree cover } \\
\text { brightness } \\
\text { value }\end{array}$ & $\begin{array}{l}\text { Map } \\
\text { centre } \\
\& \\
\text { zoom } \\
\end{array}$ & Bands & $\begin{array}{l}\text { Time } \\
\text { period }\end{array}$ \\
\hline $\begin{array}{l}\text { Forest } \\
\text { loss }\end{array}$ & $\begin{array}{l}\text { 00FF00( } \\
\text { Forest } \\
\text { cover) } \\
\text { FF00FF( } \\
\text { loss) }\end{array}$ & (150) & $\begin{array}{l}3.30, \\
107.50 \\
\& \\
10\end{array}$ & $7 / 5 / 4 / 3$ & $\begin{array}{l}2012- \\
17\end{array}$ \\
\hline $\begin{array}{l}\text { Forest } \\
\text { gain }\end{array}$ & $\begin{array}{l}\text { 00FF00( } \\
\text { Forest } \\
\text { cover) } \\
\text { 0000FF( } \\
\text { gain) }\end{array}$ & (150) & $\begin{array}{l}3.30, \\
107.50 \\
\& \\
10\end{array}$ & & $\begin{array}{l}2012- \\
17\end{array}$ \\
\hline
\end{tabular}

\section{A. Image manipulation}

The bands of satellite images are corrected and radiance value was converted into reflectance. Band 6, 5 and 4 of Landsat 7 + ETM were combined to make an image of the false color composite. Vegetation and water bodies are important characteristics of the forest land cover. Therefore, NDVI, NDWI and MNDWI analysis were applied to detect the 
vegetation as well as a water body. Water bodies may be kinds of natural lakes or the filled water body in the inactive mined area.

The NDVI can be calculated by the formula

NDVI $=(\mathrm{NIR}-\mathrm{Red}) /(\mathrm{NIR}+\mathrm{Red})$, Where as

MNDWI= (Green-MIR)/(Green+MIR),

used to specifically detect the water bodies. However, in each pixel of the study area, there is an availability of a mixture of vegetation and water bodies. Therefore, to quantify the fraction values of vagetation and water bodies present in each pixel have been calculated by the Shimbakuro formula which is mathematically represented as the spectral unmixing formula (eq. 1),

$r i=\sum_{j=1}^{n}(a i j x j)+e i$ eq. (1)

Where, ri= mean spectral reflectance

aij $=$ Spectral reflectance

ei is the error that comes from the ith band.

The results are presented in the figure present below. In figure $6 a)$, the brighter part shows the vegetation while in figure $6 \mathrm{~b}$ ), the brighter part shows water bodies. However, some water bodies

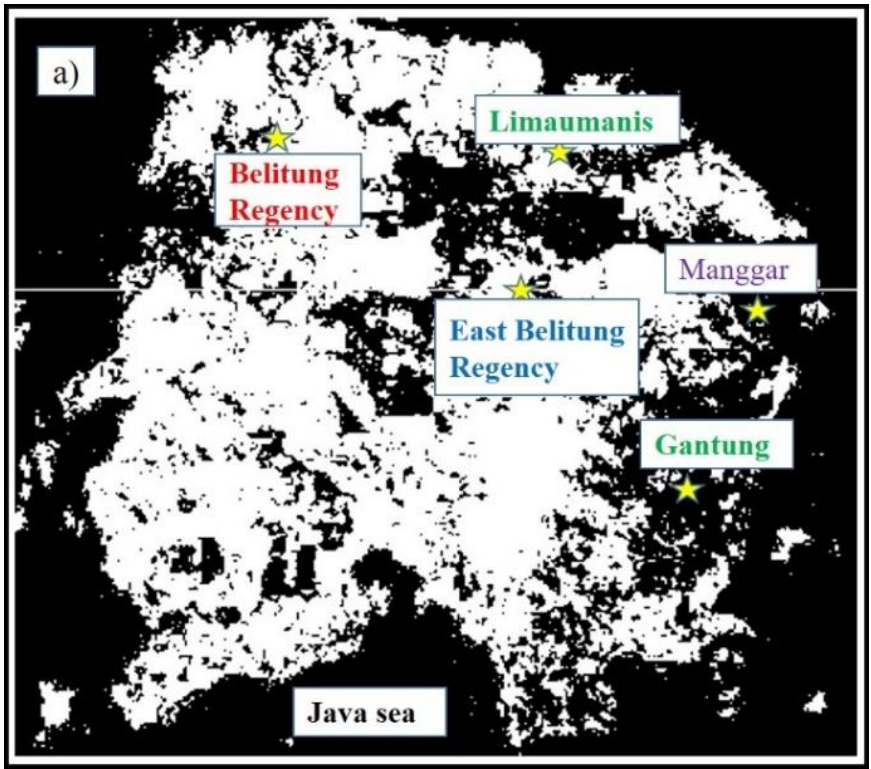

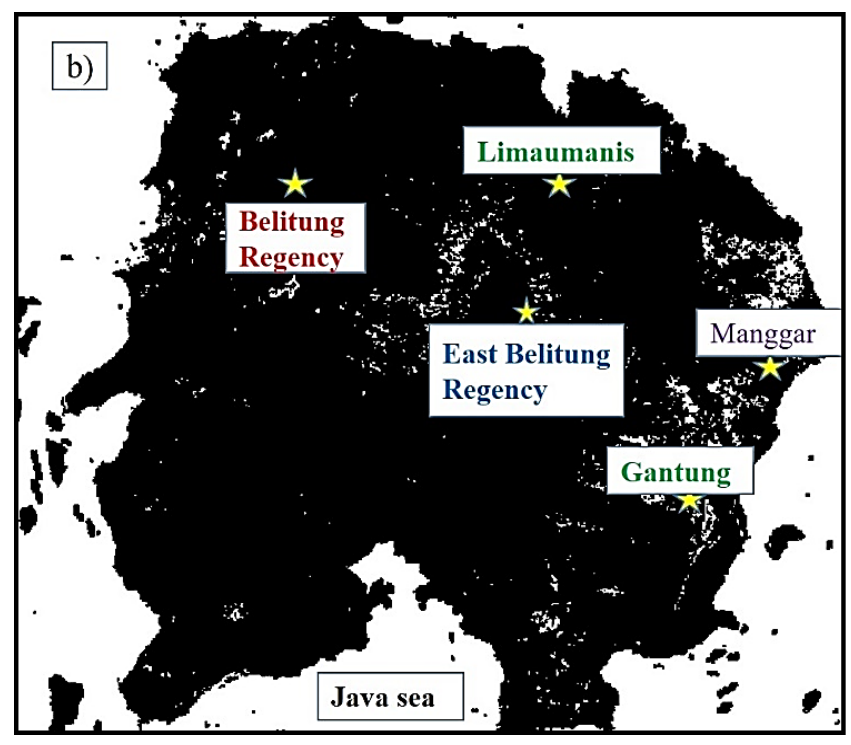

Figure 6. The details of the NDVI and MNDWI map are presented in figure a) and b) respectively.

are natural while some of them are present in the inactive mining areas. Nevertheless, some water bodies can be found in active mining areas but that is not permanent. The graph between NDVI, NDWI, MNDWI and a fitted value as compared to the NDVI and NDWI calculated and plotted in figure 7 .

Table 3. The details of NDVI and MNDWI map are presented.

\begin{tabular}{|c|c|c|c|c|c|c|}
\hline Criteria & $\begin{array}{l}\text { Map } \\
\text { centre } \\
\text { \& zoom }\end{array}$ & $\begin{array}{l}\text { No of } \\
\text { cycles } \\
\text { per } \\
\text { year }\end{array}$ & $\begin{array}{l}\text { Cloud } \\
\text { score }\end{array}$ & $\begin{array}{l}\text { Band } \\
\mathrm{s}\end{array}$ & $\begin{array}{l}\text { Fitted } \\
\text { values }\end{array}$ & $\begin{array}{l}\text { Time } \\
\text { perio } \\
\text { d }\end{array}$ \\
\hline NDVI & $\begin{array}{l}3.30, \\
107.50 \\
\& \\
10\end{array}$ & 1 & 10 & $\begin{array}{l}\text { B5, } \\
\text { B4 }\end{array}$ & $\begin{array}{l}\text { Line } \\
\text { Width: } \\
\text { 3, Point } \\
\text { Size: } 6\end{array}$ & $\begin{array}{l}2013 \\
-18\end{array}$ \\
\hline $\begin{array}{l}\text { MNDW } \\
\text { I }\end{array}$ & $\begin{array}{l}3.30, \\
107.50 \\
\& \\
10\end{array}$ & 1 & 10 & $\begin{array}{l}\text { B6, } \\
\text { B5 }\end{array}$ & $\begin{array}{l}\text { linewid } \\
\text { th: } 3 \text {, } \\
\text { Point } \\
\text { Size: } 6\end{array}$ & $\begin{array}{l}2013- \\
2018\end{array}$ \\
\hline
\end{tabular}

In the plotted graph, it is very much clear that, the values of MNDWI and NDVI are opposite to each other. NDVI is showing positive values while MNDWI represents the negative 
values. All the main mining regions are plotted in figure 6a) and $6 \mathrm{~b}$ ). This gives evidence that some water bodies are present in active and inactive mining areas. NDVI image explains that some mining activity mostly responsible for the forest loss.

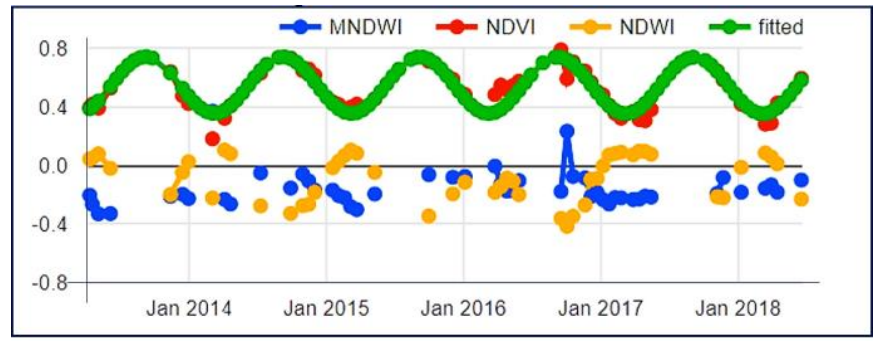

Figure 7. Represents the graph between NDVI, NDWI, MNDWI and fitted values.

\section{B. Elevation modelling}

Density slice method applied in the google earth engine platform on SRTM data to clearly projects the elevation profile to understand the uplands and lowlands in this study. Elevation analysis was applied to five selected areas of mining activity such as Gantung, Manggar, Limaumanis, Belitung regency and some parts of east belitung regency. The elevation profiles of all the selected areas are presented in figure 9. according to the projected line color, which can be seen figure 8 . The inactive mines are totally filled with water, while active mines are characterised by very large depressions. Inactive mines are characterised by younger sediments with permanent water bodies. If the analysis can be applied to all the historical data and recent data, the details of uplands and lowlands can be demontrated. Some shallow depressions can also found in the elevation graph that indicates the small patches of tin mining areas. The elevation profiles against distance indicate the tin mining areas. The boxes in the profile indicate the water bodies or lakes while other profile depressions indicate the mining areas. As the highest height of the island is $500 \mathrm{~m}$, the profile provides some areas with highest height of $0-1 \mathrm{~m}$ from the mean sea level. Therefore, it indicates the forest loss in these regions are not only because of settlements and agricultural development but also due to active and inactive tin-mining. Data has a spatial resolution of $30 \mathrm{~m}$, which gives some valuable results. In addition, by considering all the analysis of vegetation index (NDVI), water index (MNDWI), elevation modelling and forest land cover changes, it is clear that not only mining but also many other causes that are responsible for the forest changes in the island of Belitung. This analysis through google earth engine is interesting and effective for the interpretation of uplands and lowlands. However, the exact areas of depression or high lands cannot be identified. Therefore, the results of elevation profile are evident for the better interpretation of the mining areas. The profile for the water bodies must be look like plane or smooth that also can be interpret from the elevation modelling of the study area. The details of the elevation profile figures are projected below in figure 8 and 9 , respectively.

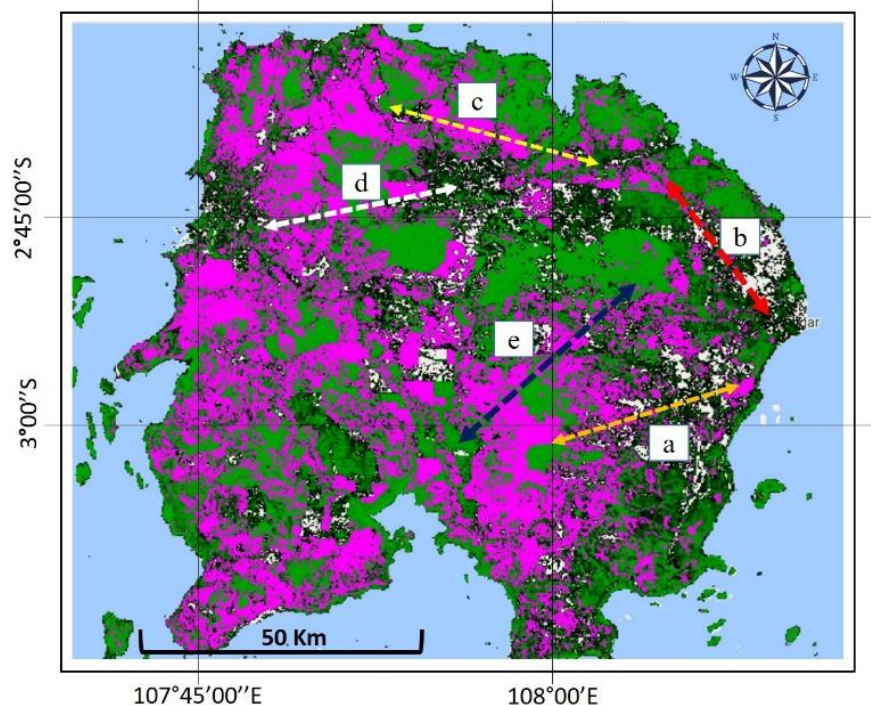

Figure 8. Elevation profile lines in different mining areas on 2017 forest loss map.

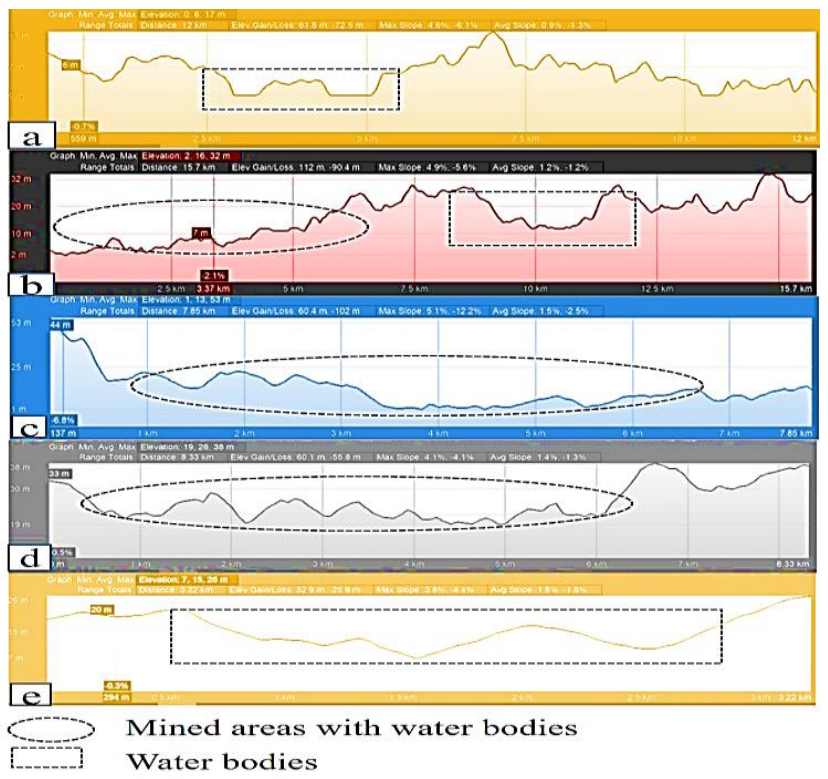

Figure 9. Elevation profile of all the selected areas of analysis.

\section{VALIDATION}


It is quite essential to visually analyse the areas of forest loss and need to make a valid correlation with mining. In this research, identification of the forest loss and gain using google earth engine JavaScript system can be helpful to make a better correlation. Therefore, we conduct the validation part to support the obtained results. Results are pixelated just because of the low quality data. However, we have used different data to understand forest loss and gain that can be used for interlinkage. For the purpose of validation, MODIS images, the google earth images of mining areas are considered. For identification and rechecking of the resulted map the validation process performed that gives the excellent correlation. According to Figure 3 and 4, the forest loss areas in Belitung Island are because of the agriculture, mining and settlement, which is correct as per the validated images. There are many places pointed as (a, a1, b, b1, c, d, e and f) in the google earth images. All the places are presented in the next figure of field images. The google earth images are presented in the figure 11 using $500 \mathrm{~m}$ scale resolution. Therefore, considering and analysing all the figures its quite clear that all the loss areas mostly due to opencast tin-mining.

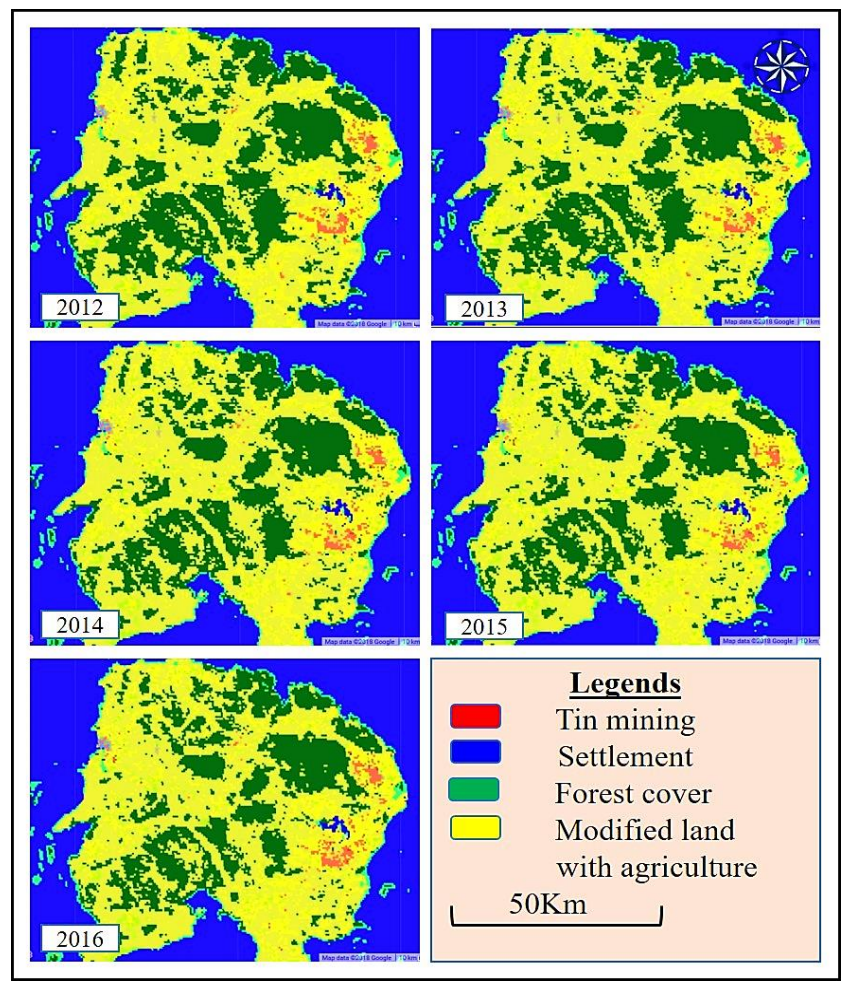

Figure 10. Represents the MODIS land cover classification images of Belitung Island.
MODIS global forestland cover images are collected from the Google earth engine workspace that can be used as a basis for land cover classification. Here, in this study, the images are collected from 2012 up to 2016 to understand the land cover changes and to detect the changes visually. Therefore, various land cover information are presented on the map with a scale of $50 \mathrm{~km}$. However, the details of MODIS image information can be collected from the USGS or from the (GEE) official site. Figure 10. represents the information of forest cover that can be correlated with our obtained result. From the google earth pro application, very high-resolution images collected to validate the results. However, the images are modified in quality and contrast for better looking. Different parts of the island that covered with mining activity have been collected from the application and presented below in figure 11. This gives evidence of active and inactive mining as well as settlements near the mining areas.

\section{CONCLUSIONS}

This research naturally limited to the mapping of the forest change and making a correlation with the mining as well as settlement. Therefore, Google earth engine is very much efficient that is the well-developed technique in remote sensing that gives appropriate correlation. Mostly, the forest loss is due to mining and human settlement. Therefore, natural carbon stock is highly affected by the mining and human settlement. Consideration of the development of forest before taking a step towards mining is necessary. The mine exposure, resource management, and various beneficial activities that can be analysed, mapped through GEE and various developmental activities can be proposed. However, the highly suggestive results for the use of (GEE) google earth engine applications are appreciable. Effective outcomes of the (GEE) google earth engine for the forestland cover analysis is highly accepted. Off course, mines carry many opportunities of job for various category of the local people and developmental work for the local community. If industrial development and mining operations are established in remotely areas then remote sensing is the only option to map and analyse the area, significantly. Nevertheless, forest loss due to mining is not good and efficient for the environmental development. Environmental pollution as well as health issues can be resulted because of mining activity by losing forests. Therefore, before mining plan there is a requirement of consideration of environmental and health issue. However, the methodology 
applied here to analyse the forestland cover is cost-effective and well developed.

\section{ACKNOWLEDGEMENT}

This research is funded by Centre for Advanced Modelling and Geospatial Information Systems, University of Technology Sydney, under grant: 323930, 321740.2232335 and 321740.2232357 .

\section{REFERENCES}

[1] Anonimous. "The Condition of Coral Reefs in Babel”. 2007, http://kompascomunity.

[2] E. Bidayani, Analisis Ekonomi Tambang Konvensional (TI) dengan Kegiatan Perikanan Tangkapdan Pariwisata di Pesisir Tanjung UlarKabupaten Bangka Barat, AkuatikJurnal Sumberdaya Perairan, Vol. 3, pp. 10-12, , (2009).

[3] Google Earth Engine. Retrieved March 10, 2016.

[4] Google Earth Engine. Retrieved February 5, 2014, from https://earthengine.google.org/\#intro.

[5] N.Gorelick, M.Hancher, M.Dixon, S. Ilyushchenko, D. Thau, R. Moore. "Google Earth Engine: Planetary-scale geospatial analysis for everyone”. Remote Sensing of Environment, vol.202, pp.18-27, 2017.

[6] D. Hermon. "Dinamika Permukimandan Arahan Kebijakan Pengembangan Permukimanpada Kawasan Rawan Longsor di Kota Padang Sumatera Barat". Disertasi, PSL IPB, Bogor, 2010a.

[7] D. Hermon. "GeografiLingkungan: Perubahan Lingkungan Global”. UNP Press, Padang, 2010 b.

[8] D. Hermon. "Mitigasi Bencana Hidrometeorologi: Banjir, Longsor, Degradasi Lahan, Ekologi, Kekeringan. dan Puting Beliung”, UNP Press, Padang, 2012a.

[9] D. Hermon. "Dinamika Cadangan Karbonakibat Perubahan Tutupan Lahanuntuk Permukiman di Kota Padang Sumatera Barat". Forum Geografi:Indonesian Journal of Spatial and Regional Analysis, Vol. 26, pp. 45-52, 2012 b.

[10] D. Hermon, "Geografi Bencana Alam. Radja Grafindo", Jakarta, 2014a.
[11] D. Hermon. "Dampak GempadanIsu Tsunami terhadap Dinamika Pendudukdan Perubahan Lingkungan di Kota Padang". Prosiding Seminar Internasional Serumpun, Riau-Malaysia, 2014b.

[12] D. Hermon. "Impacts of Land Cover Change on Climate Trend in Padang Indonesia". International Journal of Geography, Vol. 46, pp.138-142, 2014c.

[13] D. Hermon. “Arahan Mitigasi Bencana Longsor Kawasan Gunung Padang Kota Padang Sumatera Barat". JurnalGeografi, Vol. 9, pp. 1-7, 2014 d.

[14] D. Hermon. "Estimates of Changes in Carbon Stoks Based on Land Cover Changes in the Leuser Ecosystem Area (LEA) Indonesia". Forum Geografi: Indonesian Journal of Spatial and Regional Analysis, Vol. 29: pp.187-196, 2015.

[15] K. Keenan, J. Echave, and K. Traynor. "Mining and Communities: Poverty Amidst Wealth". Political Economy Research Institute, University of Massachusetts, Conference Paper Series, No.3, 2002.

[16] B. Lusiana, N. Meine, R. Surbekti, "CadanganKarbon di Kabupaten Nunukan kalimantan Timur". Monitoring Secara Spasialdan Pemodelan, ICRAF, Bogor, 2005.

[17] J.J. Marchus, Mining Environmental Handbook. 1997.

[18] D. Murdiyarso, CDM: Mekanisme Pembangunan Bersih. Kompas, Jakarta, 2003 b.

[19] E.A. Ripley, R.E. Redman, and A.A. Crowder. “Environmental Effects of Mining”. 1996.

[20] N.C. Saxena, G. Singh and R. Gosh. Environmental Management in Mining Areas. 2002.

[21] R.K. Suri, O.N. Kaul, and S.P. Banerjee. "Mining, Environmet, and Forests". 1996.

[22] M.S. Tehrany, B. Pradhan, and M.N. Jebur. "Remote sensing data reveals eco-environmental changes in urban areas of Klang Valley, Malaysia: contribution from object based analysis". Journal of the Indian Society of Remote Sensing, vol. 41(4), pp.981-991, 2013.

[23] M.S. Tehrany, B. Pradhan, and M.N. Jebur. "A comparative assessment between object and pixel-based 
classification approaches for land use/land cover mapping using SPOT 5 imagery". Geocarto International, vol. 29(4), pp.351-369, (2014) .

[24] S. Abdullahi, and B. Pradhan. "Sustainable brownfields land use change modeling using GIS-Based weights-ofevidence approach". Applied spatial analysis and policy, vol. 9(1), pp.21-38, (2016).

[25] H. Nampak, B. Pradhan, H.R. Mojaddadi, and H.J. Park. "Assessment of land cover and land use change impact on soil loss in a tropical catchment by using multitemporal SPOT- 5 satellite images and Revised Universal Soil
Loss Equation model". Land degradation \& development, vol. 29(10), pp.3440-3455, (2018).

[26] B. Pradhan. "GIScience Tools for climate change related natural hazards and modelling". In Geoinformatics for Climate Change Studies. The Energy and Resources Institute New Delhi, India, (2011). 